\title{
The Long-Term Development of Local Retail and Services Sectors in Rural Southern Counties
}

\section{George Hammond and Eric Thompson*}

\begin{abstract}
This research examines the trend in retail and services capture, as measured by location quotients, in counties throughout the South from 1969 to 1997. Analysis indicates that location quotients have been falling on average in nonmetropolitan and trade shed counties in the retail and services industries. However, location quotient values have not, in general, been converging to any particular value. Further, there is substantial mobility (both upward and downward) in county location quotients over time. Both findings suggest that there is potential for success with public policy programs designed to help local communities capture more local spending.
\end{abstract}

\section{INTRODUCTION}

The declining downtowns, closing hospitals, and abandoned country stores often observed in rural areas have raised concerns about the strength of the retail and services industries in the nonmetropolitan United States (Flora et al. 1992). These concerns persist even in an environment of rising retail and services employment throughout the nation, including in many nonmetropolitan areas. The concern thus may not reflect so much an absolute decline in employment, but that local retail capture could be falling, with sales presumably lost to nearby urban areas or selected rural communities. A fall in the capture of local spending power would represent a lost opportunity for employment and earnings within nonmetropolitan counties.

The issue of retail capture has been one focus of rural economic development efforts. Economic development programs to help communities capture more of the local retail and services spending dollar, such as downtown redevelopment programs, have been in operation in nonmetropolitan areas. These programs have had some success. One natural question, however, is whether economic trends are working in favor of or against such collective efforts to improve the capture of resident spending.

To address this question, this research examines both the trend and distribution of retail (and services) capture among counties throughout the South from 1969 to 1997 . Several previous studies also have measured trends in retail capture among nonmetropolitan areas in the United States (Gale 1996; Yanagida et al. 1991). However, our additional focus on changes in the distribution yields a number of new insights into the ability of individual counties to improve or maintain

*Research Assistant Professor, Bureau of Business and Economic Research, West Virginia University; and Research Assistant Professor and Associate Director, Center for Business and Economic Research, University of Kentucky. This research was supported by the TVA Rural Studies Competitive Contract Program and was presented at the 1999 meetings of the Southern Regional Science Association in Richmond, Virginia. 
their capture of local spending. This study also is the first to focus on the local capture of spending in services industries.

In this study, location quotient trends and distributions are examined for all counties, as well as in subgroups, such as nonmetropolitan counties, metropolitan counties, Rand $\mathrm{McNally}$ trade center counties, and trade shed counties. The location quotient concept used involves ratios of worker earnings in the retail or services industry divided by county total personal income. This location quotient concept is quite similar to the retail capture measure, which is based on the ratio of sales to population. However, it focuses directly on the issue of earnings, which, along with employment, is often the primary concern in development efforts.

We begin by examining the simple time trend in these location quotients overall and within metropolitan/nonmetropolitan and trade center/trade shed groups. This overall trend is naturally of interest for understanding the changing organization of the retail and services industries across space. Though able to be interpreted differently, falling location quotients may mean that efforts to improve retail capture are not worthwhile compared to other uses for economic development resources, such as encouraging the growth of manufacturing or other basic industries. Falling location quotients may also mean that there must be renewed emphasis on improving retail capture in order to reverse the trend.

A less ambiguous result for local development policy might be provided by findings regarding changes in the distribution of location quotients over time both overall and across metropolitan/trade center classifications. A finding of convergence of location quotients to a particular range of values would suggest that the capture of local spending power is becoming more homogenous over time either overall or within groups. Such a deterministic pattern would portend well for counties that have done particularly poorly in the past, because of the implication that below-average counties will have a tendency to catch up to the mean. However, it also would raise doubts about efforts to alter dramatically any particular county's capture of local spending. This would be particularly true if it is also found that there is very little mobility within the location quotient distribution for retail trade or services across time, so that counties with low location quotients rarely "leapfrog" up to have relatively high location quotients, or vice versa.

Thus, change in the distribution of location quotients over time is the focus of the research presented below. Specifically, we adapt the recent work on convergence in per capita incomes among countries or regions to the case of retail (and services) capture by examining location quotient distributions. We begin by applying the measures of Beta-convergence and Sigma-convergence (utilized by Sala-i-Martin 1996, among numerous others, to examine convergence in incomes among countries and among regions within countries) to the case of retail trade and services industry location quotients. We then take the approach utilized by Quah (1993a, 1993b, 1996a, 1996b) to more completely analyze mobility in the distribution. 
This report proceeds as follows: Section 2 reviews the relevant literature on the location of retail and services activity. Section 3 introduces the data and empirical methodology employed to analyze convergence. Section 4 presents our results and Section 5 concludes the report.

\section{BACKGROUND AND LITERATURE}

This section considers the factors that influence the location pattern of retail and services activity within regions and, therefore, might influence location quotient values. These factors may explain why location quotients differ among counties in the United States, and why location quotient values have been changing over the last few decades.

\section{A. Location of Retail and Services Activity}

Central place theory provides a framework for analyzing the location of retail and services activity in a rural-urban continuum. It can be used to generate expectations about which size places will capture certain types of retail and services activity. Central place theory is focused on the market size and range of goods and services (Christaller 1933). Market size refers to the number of customers needed to sustain the production of a particular good or service. Alternatively, it could refer to the cost-minimizing size of a particular type of business, so that a business could exist while serving fewer customers than required at its costminimizing size, but it would produce the good or service at a higher cost. The range of the good refers to the willingness of customers to travel in order to purchase the good, which would tend to be higher in those cases in which travel costs are small relative to the total cost of purchase. For example, more expensive items, such as automobiles or appliances, would have a higher market range since travel costs are small relative to overall costs. Products that infrequently require customers to travel to use them, such as insurance or some financial services, also have small travel costs relative to overall costs.

In central place theory, the production of a good or service is allocated to different economic places (communities or counties, for example) based on its market size and range. Businesses that require relatively few customers to produce at or near the cost-minimizing size tend to be located in nearly every place. However, businesses that have a large market range and require a large number of customers, either because the average customer spends little on the good (e.g., specialty stores), or because there are great economies of scale in production, will tend to be located in only the largest places. Larger places that have producers of most types of goods and services are called higher order places, and smaller places that house producers of relatively few types of goods and services are called lower order places. Naturally, there is a continuum of places between the lowest and highest order places.

Residents of lower order places must travel to nearby higher order places in order to purchase a number of goods or services (or purchase them at a lower 
price). Leakage of consumer dollars is highest in the lower order places and declines in higher order places. This suggests that counties comprised of only the lowest order towns will tend to have relatively low capture of local spending as much spending leaks outside the county. Counties comprised of higher order places will have less leakage, and will attract out-of-county customers for locally produced goods and services, leading to both a high capture of local spending and the capture of additional spending. Total retail and services activity will exceed what can be supported by local income.

Therefore, compared to the average place, a higher order place would have a high level of retail and services activity compared to its purchasing power. A lower order place would have a low level of retail and services activity compared to its purchasing power. This characterization suggests a location quotient-type measure for assessing the degree to which a particular region or county is a higher order place or a lower order place. The location quotient would be:

$$
\mathrm{LQ}_{\mathrm{i}, \mathrm{c}}^{\text {earn }} / \mathrm{pi}=\frac{\text { Earnings }_{\mathrm{i}, \mathrm{c}}}{\text { Personal Income }_{\mathrm{c}}} \div \frac{\text { Earnings }_{\mathrm{i}, \text { south }}}{\text { Personal Income }_{\text {south }}} .
$$

This location quotient measure examines for two places the activity in industry $i$ (for example, retail or services) relative to income, which is used as a proxy for purchasing power, and then compares the two ratios. These two places are the particular county of interest and the "average" place, which is signified by some larger region, in this case the South Census region of the United States. Thus, the measure indicates how effectively a place, county c, captures its local spending power compared to the average place. The use of personal income as a proxy for spending power is imperfect since it assumes that all personal income is disposable income available for spending and ignores the retail and service purchases of businesses. However, as is reported later, we find that our results do not change significantly if we exclude from Equation 1 medical transfer payment income, which is dedicated to health care spending rather than part of the disposable purchasing power of county residents. We also find that our results do not change substantially in the case of specific retail or service industries that rely heavily on business purchases, although there are some differences in the case of business services and travel related industries.

Note also that the level of activity in the retail or services industry is measured using worker earnings by industry, where earnings includes wages and salaries, fringe benefits, and proprietors' income. This approach is appropriate because the capture of local spending is often an issue because towns or counties wish to maintain more job and earnings opportunities in their local area. In addition, worker earnings is typically a large component of output in any services industry or a large component of the markup in any retail industry, so changes in earnings should mirror changes in overall industry output and sales. Indeed, there appears to be a consistent relationship between earnings and sales even in 
the retail trade industry, where the wholesale costs of goods comprise a large share of the retail price. Using data from the 1997 Kentucky Census of Retail Trade, we found that worker earnings accounted for between 7 percent and 10 percent of total retail sales in 84 percent of counties in the state.

In terms of Equation 1, the lower order place would be less successful at capturing its local spending, which would be signified by a location quotient value below 1.0. A higher order place would be more successful at capturing its local spending, and also would capture spending from surrounding areas, which would be signified by a location quotient value above $1.0{ }^{1}$

Finally, the location quotient measure is not all that different from the trade-area capture measure used by some other authors (Yanagida et al. 1991; Shonkwiler and Harris 1996; Harris and Shonkwiler 1997). The trade-area capture measure looks at the sales of a county in relation to the population of its trade area. In fact, the location quotient measure may have several advantages over the trade-area capture measure. First, it focuses on worker earnings (which in turn is related to employment) rather than sales, and employment and earning opportunities are in many cases a higher policy concern than sales, unless sales tax revenue is the issue. This is particularly true in the retail trade industry, in which a large portion of the retail sale price of items is the wholesale value of the good sold rather than the retail markup. However, since the goods sold typically are not produced locally, it is the size of the markup, of which worker earnings is a large component, that determines the impact of retail activity on the local economy, rather than the size of the sale. Second, income is a better measure than population since the income measure adjusts for different levels of per capita income found in different places.

\section{B. Changes in Location Quotients Over Time}

There are a number of reasons to expect that location quotient values may have changed systematically in nonmetropolitan counties over the last three decades. These issues also are discussed in Gale (1996). First, the optimal (costminimizing) size for many types of retail or services establishments may have risen dramatically in recent years. This is best exemplified by the growth in megastores, such as Kmart and Walmart, Lowe's home improvement warehouse, automalls, and large supermarkets. A rise in the optimal size of such retail and services establishments implies that establishments require a larger market. This factor may have caused many types of retail and services activities to gradually concentrate in higher order places in the last few decades.

At the same time that market size has been rising for many retailers and services providers, the ranges of these goods have expanded, further encouraging concentration in higher order places. Ranges have expanded as transportation costs have fallen over the last few decades due to improvements in automobile

${ }^{1}$ Yet, the interpretation of location quotient measures regarding the capture of local spending is made somewhat uncertain due to unknown levels of cross-hauling or differing tastes and preferences among residents of different counties (Shaffer 1989). 
design, declines in real fuel costs, better roads, and a rise in the percentage of rural residents with a driver's license. Falling transportation costs have made it harder Several recent studies have demonstrated the importance of central place theory in explaining the location of retail and services activity. The location of retail activity within nonmetropolitan counties has been a subject of research by Yanagida et al. (1991), Shonkwiler and Harris (1996), Gale (1996), and Harris and Shonkwiler (1997). The studies by Shonkwiler and Harris have focused on the interdependence of establishment location in different retail sectors. These authors concluded that the presence of an establishment in one type of retail activity (a building supply store, for example) increased the likelihood of having an establishment in other types of retail sectors (a furniture store, for example). This finding of the importance of economies of scope tends to enhance the argument of central place theory by giving yet another reason why retail activity might concentrate in larger places. Larger counties are more likely to have a lumber store and, therefore, are also more likely to have a department store.

Yanagida et al. (1991) examined county characteristics that help counties capture a larger share of retail spending by their residents. The authors found that larger counties and counties located farther from trade centers capture a larger share of resident retail spending, as would be expected following central place theory.

Gale (1996) examined pull factors for counties throughout the United States. Gale (1996) found that pull factors were higher and steady in the trade center counties in Rand McNally trade areas, but falling in the trade shed counties, particularly in the most rural counties. Population density also was associated with higher pull factors, and pull factors were on average lower in the South Census region.

\section{METHOD}

\section{A. Measuring Distributional Dynamics}

Trends in the level and distribution of location quotients over time are the focus of this paper. To analyze changes in the location quotient distributions, we employ the empirical methods developed to examine economic convergence across regions.

There have been significant developments in the literature on economic convergence in recent years (see, for example, Sala-i-Martin 1996; Quah 1993a; Carlino and Mills 1996). This research has developed both regression models to test for convergence and methods that look at convergence by closely examining the evolution of the income distribution over time. These techniques have been designed to shed light on the economic theory that incomes should converge among nations over time (Mankiw, Romer, and Weil 1992; Sala-i-Martin 1996), or among regions in a nation (Barro and Sala-i-Martin 1991 and Carlino and Mills 1996 for the U.S.; Chatterji and Dewhurst 1996 for Great Britain; and Hofer and Woergoetter 1997 for Austria). Similar methods have also been used to examine 
convergence in productivity levels across regions and industries (Bernard and Jones 1996 for the U.S.) and across regions for a particular industry (the services sector in the U.K. in Button and Pentecost 1993).

One way for convergence to occur is for a low-ranked region to grow faster than a higher-ranked region. This mobility condition can be tested in a cross section framework by regressing regional growth rates on regional starting levels. If low-ranked regions generally tend to grow faster than more highly ranked regions then the coefficient on starting levels (commonly called Beta) will be negative and significantly different from zero. If Beta is found to be negative and significantly different from zero, then this provides support for Beta-convergence.

However, as Quah (1993a, 1993b, 1996a, 1996b) and Sala-i-Martin (1996) point out, that is not necessarily the complete story. In particular, Quah (1993a) has demonstrated that a negative Beta coefficient can occur in the absence of convergence. Imagine, for example, that low-ranked regions exactly switch places with higher-ranked regions, with no change in the overall shape of the distribution over time. We would observe Beta-convergence, even though most observers would conclude that there has been no convergence.

This, in turn, suggests that it would be useful to also examine whether the distribution has been converging in the sense of its standard deviation. If the log standard deviation of the distribution has declined over time, then that is generally referred to as evidence in favor of Sigma-convergence. We investigate this by computing the log standard deviation of location quotients as follows:

$$
\operatorname{lnStdDev} v_{i, t}=\left[[1 / C] \sum_{c=1}^{c}\left[\ln L Q_{c, i, t}-M_{e a n L Q_{i, t}}\right]^{2}\right]^{\frac{1}{2}},
$$

where $C$ is the total number of counties, $i$ indexes the industry, $t$ indexes time, and MeanLQ is calculated as follows:

$$
\text { MeanLQ } Q_{i, t}=[1 / C] \sum_{c=1}^{c} \ln L Q_{c, i, t} .
$$

Evidence of both Beta-convergence and Sigma-convergence would provide stronger evidence that convergence overall was occurring.

Finally, Quah (1993a) points out that it is possible for the researcher to observe both Beta-convergence and Sigma-convergence, but for the distribution to be very different from what one might expect. Imagine, in this case, that we have a bimodal distribution, where the "twin peaks" get slightly closer together over time. This distribution could exhibit both Beta- and Sigma-convergence, but would not be converging to a single value over time.

Quah's suggested solution is to examine both distributional modality and mobility. Modality refers to whether the distribution tends to be unimodal or 
multimodal. Mobility refers to whether there is substantial rank switching within a distribution over time, and allows for both upward and downward mobility. Quah argues that this empirical methodology matches best the intuitive concept of convergence.

\section{B. Measuring Location Quotients}

The purpose of this paper is to examine the distribution of retail trade and services industry location quotients across counties in the South Census region of the U.S. ${ }^{2}$ Location quotient values are defined in Equation 1 above using data gathered for the years 1969, 1979, and 1997 from the Regional Economic Information System data base released in August 1999 by the U.S. Department of Commerce. With this data, it is possible to examine the trends in convergence or divergence among location quotients over time.

The retail trade and services industries were selected for study because in most counties these are the two largest private locally oriented industries. These two industries also have relatively few problems with nondisclosure. ${ }^{3}$

As was discussed earlier, central place theory implies that different types of counties will have different levels of location quotients. As a result, analysis was conducted using all available counties, as well as metropolitan/nonmetropolitan counties and trade center/trade shed counties. We classify counties as trade center/trade shed using Rand McNally Trade Areas (Rand McNally and Company 2000), which are multicounty regions whose residents make the bulk of their shopping goods purchases in the trade center city (or its suburbs). Trade center counties are those counties that contain a trade center city. Trade shed counties are those counties that do not contain a trade center city.

The movement of location quotients was examined over three time periods: from 1969 to 1997,1969 to 1979 , and 1979 to 1997 . The year 1979 was chosen to break the 28-year period from 1969 to 1997 near its midpoint and also because the national economy was in a severe recession in the early 1980s. Location quotients from the early 1980s may have been affected by the recession. The year 1979 was the last year before the 1980s recession, so it was chosen over 1982, even though that year is the actual midpoint.

\section{RESULTS}

This section presents analysis of the movements of county location quotients for services and retail trade in the South Census region. We begin by examining the levels and trends of South Census region location quotients by metropolitan/

\footnotetext{
${ }^{2}$ The South Census region includes Alabama, Arkansas, Delaware, District of Columbia, Florida, Georgia, Kentucky, Louisiana, Maryland, Mississippi, North Carolina, Oklahoma, South Carolina, Tennessee, Texas, Virginia, and West Virginia. This analysis used only the counties in these states that did not have missing (or nondisclosed) data in 1969, 1979, or 1997. Retail Trade includes SICs 52-59. Services includes SICs 70-89.

${ }^{3}$ Nondisclosure occurs for a county when there are so few businesses in a particular industry that disclosing total industry employment or earnings would reveal information about particular firms. Nondisclosure at the major industry group level usually occurs in smaller counties, but is rare among the major industry groups like retail trade and services. However, nondisclosure is more common among other private major industry groups such as finance, insurance, and real estate (FIRE) and, especially, wholesale trade.
} 
trade center classification. We next analyze Beta- and Sigma-convergence and then turn to a more direct examination of distributional mobility issues. In all cases, we present results for both retail trade and services, disaggregated by metropolitan/ nonmetropolitan and trade center/trade shed status.

\section{A. Location Quotient Trends}

Table 1 summarizes trends in location quotient values across different classes of counties over the last three decades. South Census region location quotient values are presented for metropolitan/nonmetropolitan counties, trade center/ trade shed counties, and year. After accounting for nondisclosure, there were 1,382 counties available for retail trade and 1,310 for services.

Overall, mean location quotients have exhibited a downward trend during the 1969 to 1997 period, with the average location quotient for retail trade falling from 0.92 in 1969 to 0.81 by 1997. Figure 1 shows the distribution of retail trade location quotients in 1969 and 1997 and reports the mean and the log standard deviation of the distribution. As Figure 1 illustrates, the distribution has shifted, with more counties registering location quotients below 1.0 in 1997 than in 1969. This shift was also accompanied by an increase in the spread in the distribution, indicated by the rise in the log standard deviation. Together, these two factors imply an increase in inequality in the location quotient distribution, with selected counties maintaining or increasing the level of their location quotient and most other counties registering declines.

FIGURE 1

Distribution of Retail Trade

Location Quotients

1969

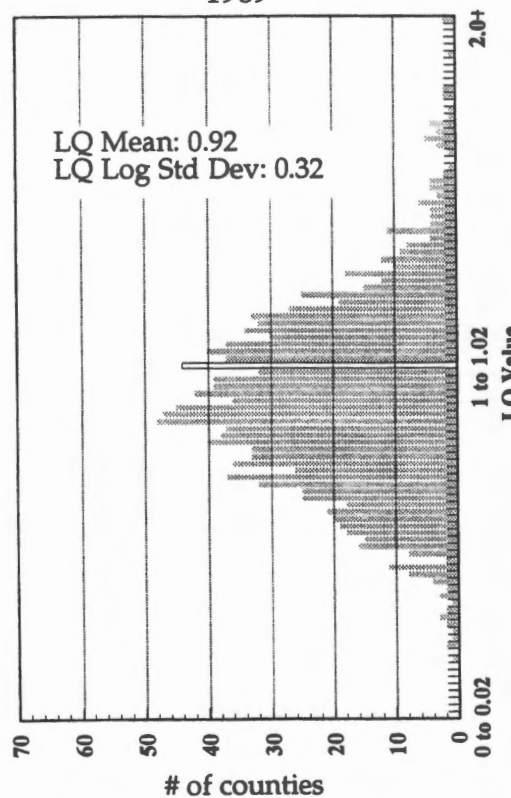

1997

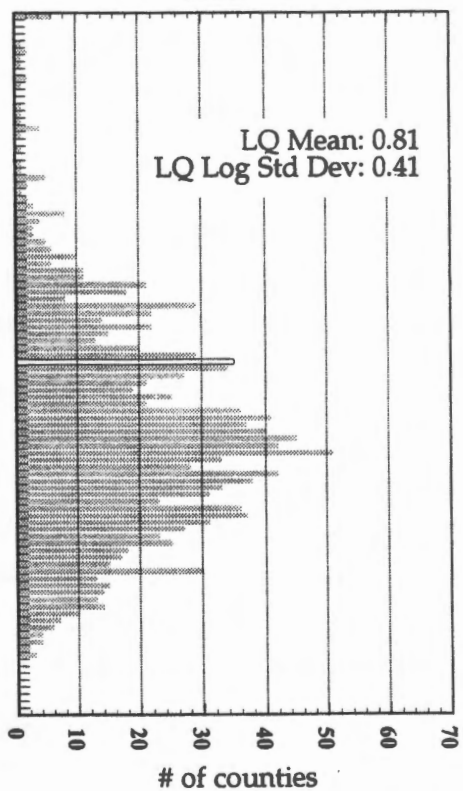


Services exhibits a similar but exaggerated trend, with the average location quotient falling from 0.73 in 1969 to 0.55 by 1997. As Figure 2 shows, the shape of the distribution of services location quotients has changed dramatically during the 28-year period, with a strong decline in the average (unweighted) location quotient and an increase in the log standard deviation. Indeed, 923 counties had services location quotients less than 0.6 in 1997, while in 1969 only 492 counties had location quotients less than 0.6 . The distribution of services location quotients shows a stronger tendency toward inequality than does the distribution of retail trade location quotients.

FIGURE 2

Distribution of Services

Location Quotients

1969

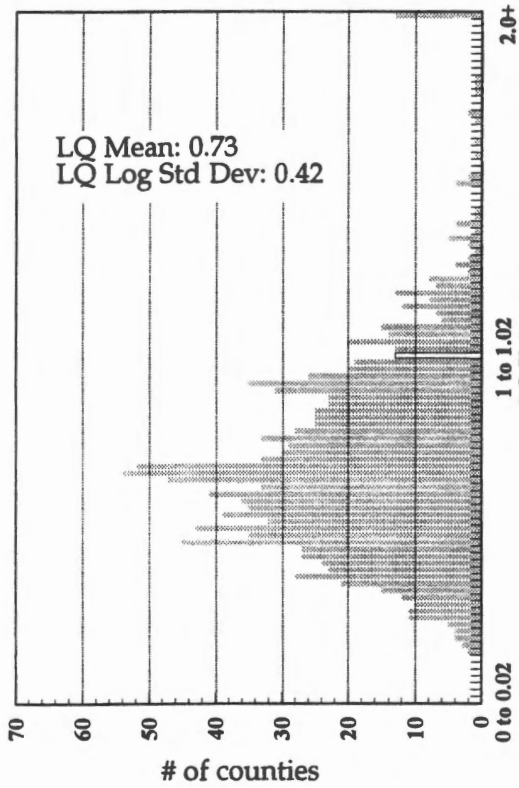

1997

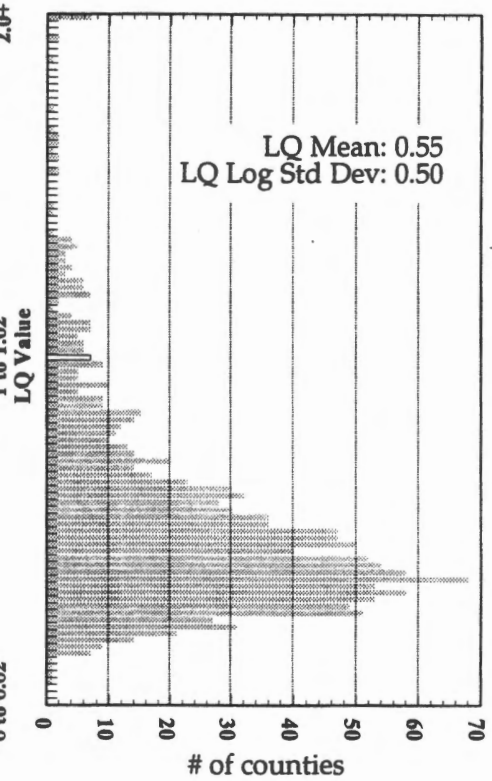

As Table 1 shows, we generally find that location quotient levels are lower in the nonmetropolitan counties than in metropolitan counties. Further, trade center location quotients are also generally greater than 1.0 and higher than they are for trade sheds, which is consistent with central place theory. Within the retail trade distribution, this pattern remains when we consider metropolitan and nonmetropolitan trade centers/trade sheds, but for the services distribution, location quotients for all but metropolitan trade center counties average less than 1.0.

Trends among location quotients over time suggest that retail and services activity has further concentrated up the central place hierarchy. Average retail trade location quotient values have remained fairly steady for metropolitan and nonmetropolitan trade center counties and for metropolitan trade shed counties, but have fallen strongly for nonmetropolitan trade shed counties. These results 
are generally consistent with those of Gale (1996), who found that retail pull factors dropped for nonmetropolitan trade shed counties.

Such a concentration of activity also has taken place in the services industry, but it has been even more selective, occurring only in metropolitan trade centers. In particular, location quotient averages have remained steady in metropolitan trade center counties during the 1969 to 1997 period, but have fallen in nonmetropolitan trade center and trade shed counties as well as in metropolitan trade shed counties.

\section{TABLE 1}

Means of Location Quotients

South Census Region Counties: 1969, 1979, 1997

\begin{tabular}{lrrrrrrrr}
\hline & $\begin{array}{c}\text { Number of } \\
\text { Counties }\end{array}$ & \multicolumn{2}{c}{ Retail Trade } & \multicolumn{5}{c}{ Number of } \\
& 1969 & 1979 & 1997 & Counties & 1969 & 1979 & 1997 \\
\hline South & 1,382 & 0.92 & 0.83 & 0.81 & 1,310 & 0.73 & 0.62 & 0.55 \\
Metropolitan & 383 & 0.88 & 0.87 & 0.89 & 372 & 0.79 & 0.75 & 0.73 \\
$\begin{array}{l}\text { Nonmetropolitan } \\
\text { Trade Center }\end{array}$ & 999 & 0.93 & 0.81 & 0.78 & 938 & 0.70 & 0.56 & 0.48 \\
$\begin{array}{l}\text { Trade Shed } \\
\text { Mraces }\end{array}$ & 1,181 & 1.12 & 1.13 & 1.13 & 200 & 1.01 & 1.00 & 0.97 \\
$\begin{array}{l}\text { Metropolitan/ } \\
\text { Trade Center }\end{array}$ & 132 & 1.13 & 1.16 & 1.15 & 132 & 1.05 & 1.08 & 1.07 \\
$\begin{array}{l}\text { Nonmetropolitan/ } \\
\text { Trade Center }\end{array}$ & 69 & 1.12 & 1.08 & 1.10 & 68 & 0.91 & 0.84 & 0.78 \\
$\begin{array}{l}\text { Metropolitan/ } \\
\text { Trade Shed }\end{array}$ & 251 & 0.75 & 0.72 & 0.76 & 240 & 0.65 & 0.57 & 0.55 \\
$\begin{array}{l}\text { Nonmetropolitan/ } \\
\text { Trade Shed }\end{array}$ & 930 & 0.92 & 0.79 & 0.76 & 870 & 0.68 & 0.54 & 0.46 \\
\hline
\end{tabular}

Notes: Location quotient as defined in Equation 1. Metropolitan counties are counties with Beale Codes 0 to 3. Nonmetropolitan counties are counties with Beale Codes 4 to 9. Trade Center counties are counties that contain trade center cities in Rand McNally Trade Areas. Trade Shed counties are counties within Rand McNally Trade Areas that do not contain a trade center city.

\section{B. Beta- and Sigma-Convergence}

\section{i. Aggregate Results}

In order to examine Beta-convergence for location quotients in the South Census region, we estimate a growth rate regression of the following form:

$$
\left(\ln L Q_{c, i, t+n}-\ln L Q_{c, i, t}\right) / n=\alpha+\beta \ln L Q_{c, i, t}+\gamma X_{c, i, t}+\varepsilon_{c, i},
$$

where $L Q$ is a location quotient, $X$ is a vector of control variables, which includes the log of county population density and the log of the distance from the trade center county (for trade shed counties), $c$ indexes counties, $t$ is the initial time period, $\mathrm{n}$ is the length of the time period, and $\mathrm{i}$ indexes industry. ${ }^{4}$ If Beta is negative, then counties with lower starting location quotients tend to exhibit faster growth, and vice versa.

${ }^{4}$ Population density is the ratio of county population to county area (in square miles). Distance from trade center counties is computed using Rand McNally Trade Area definitions and county centroids. 
As the first row of Table 2 shows, tests for Beta-convergence indicate significant mobility in both retail and services location quotients for the South Census region during all three periods considered. Our results (available from the authors upon request) also show that counties with higher population density tend to register faster location quotient growth and that trade shed counties that are farther from the trade center tend to have slower location quotient growth.

TABLE 2

Beta- and Sigma-Convergence Results South Census Region Counties

\begin{tabular}{|c|c|c|c|c|c|c|c|c|c|c|c|c|}
\hline \multirow[b]{2}{*}{ t } & \multicolumn{6}{|c|}{ Retail Trade } & \multicolumn{6}{|c|}{ Services } \\
\hline & $\begin{array}{c}\text { Beta } \\
\text { 1969-97 } \\
\text { P-Value }\end{array}$ & $\begin{array}{c}\text { Beta } \\
\text { 1979-97 } \\
\text { P-Value }\end{array}$ & $\begin{array}{c}\text { Beta } \\
\text { 1969-79 } \\
\text { P-Value }\end{array}$ & $\begin{array}{l}\text { Log } \\
\text { Std } \\
\text { Dev } \\
1969\end{array}$ & $\begin{array}{l}\text { Log } \\
\text { Std } \\
\text { Dev } \\
1979\end{array}$ & $\begin{array}{l}\text { Log } \\
\text { Std } \\
\text { Dev } \\
1997\end{array}$ & $\begin{array}{c}\text { Beta } \\
1969-97 \\
\text { P-Value }\end{array}$ & $\begin{array}{c}\text { Beta } \\
\text { 1979-97 } \\
\text { P-Value }\end{array}$ & $\begin{array}{c}\text { Beta } \\
1969-79 \\
\text { P-Value }\end{array}$ & $\begin{array}{l}\text { Log } \\
\text { Std } \\
\text { Dev } \\
1969\end{array}$ & $\begin{array}{l}\text { Log } \\
\text { Std } \\
\text { Dev } \\
1979\end{array}$ & $\begin{array}{l}\text { Log } \\
\text { Std } \\
\text { Dev } \\
1997\end{array}$ \\
\hline South & $\begin{array}{r}-0.010 \\
0.000\end{array}$ & $\begin{array}{r}-0.009 \\
0.000\end{array}$ & $\begin{array}{r}-0.014 \\
0.000\end{array}$ & 0.32 & 0.36 & 0.41 & $\begin{array}{r}-0.017 \\
0.000\end{array}$ & $\begin{array}{r}-0.017 \\
0.000\end{array}$ & $\begin{array}{r}-0.029 \\
0.000\end{array}$ & 0.42 & 0.45 & 0.50 \\
\hline Metropolitan & $\begin{array}{r}-0.016 \\
0.000\end{array}$ & $\begin{array}{r}-0.008 \\
0.000\end{array}$ & $\begin{array}{r}-0.025 \\
0.000\end{array}$ & 0.35 & 0.37 & 0.39 & $\begin{array}{r}-0.018 \\
0.000\end{array}$ & $\begin{array}{r}-0.012 \\
0.000\end{array}$ & $\begin{array}{r}-0.031 \\
0.000\end{array}$ & 0.45 & 0.50 & 0.56 \\
\hline Nonmetropolitan & $\begin{array}{r}-0.008 \\
0.000\end{array}$ & $\begin{array}{r}-0.009 \\
0.000\end{array}$ & $\begin{array}{r}-0.012 \\
0.000\end{array}$ & 0.30 & 0.35 & 0.41 & $\begin{array}{r}-0.017 \\
0.000\end{array}$ & $\begin{array}{r}-0.019 \\
0.000\end{array}$ & $\begin{array}{r}-0.030 \\
0.000\end{array}$ & 0.41 & 0.40 & 0.43 \\
\hline Trade Center & $\begin{array}{r}-0.019 \\
0.000\end{array}$ & $\begin{array}{r}-0.015 \\
0.000\end{array}$ & $\begin{array}{r}-0.021 \\
0.000\end{array}$ & 0.17 & 0.17 & 0.19 & $\begin{array}{r}-0.015 \\
0.000\end{array}$ & $\begin{array}{r}-0.013 \\
0.000\end{array}$ & $\begin{array}{r}-0.023 \\
0.000\end{array}$ & 0.29 & 0.31 & 0.34 \\
\hline Trade Shed & $\begin{array}{r}-0.010 \\
0.000\end{array}$ & $\begin{array}{r}-0.009 \\
0.000\end{array}$ & $\begin{array}{r}-0.017 \\
0.000\end{array}$ & 0.32 & 0.34 & 0.40 & $\begin{array}{r}-0.018 \\
0.000\end{array}$ & $\begin{array}{r}-0.019 \\
0.000\end{array}$ & $\begin{array}{r}-0.032 \\
0.000\end{array}$ & 0.41 & 0.40 & 0.43 \\
\hline $\begin{array}{l}\text { Metropolitan/ } \\
\text { Trade Center }\end{array}$ & $\begin{array}{r}-0.018 \\
0.000\end{array}$ & $\begin{array}{r}-0.010 \\
0.017\end{array}$ & $\begin{array}{r}-0.021 \\
0.000\end{array}$ & 0.17 & 0.16 & 0.19 & $\begin{array}{r}-0.014 \\
0.000\end{array}$ & $\begin{array}{r}-0.008 \\
0.004\end{array}$ & $\begin{array}{r}-0.025 \\
0.000\end{array}$ & 0.30 & 0.31 & 0.35 \\
\hline $\begin{array}{l}\text { Metropolitan/ } \\
\text { Trade Shed }\end{array}$ & $\begin{array}{r}-0.017 \\
0.000\end{array}$ & $\begin{array}{r}-0.010 \\
0.000\end{array}$ & $\begin{array}{r}-0.029 \\
0.000\end{array}$ & 0.32 & 0.33 & 0.38 & $\begin{array}{r}-0.018 \\
0.000\end{array}$ & $\begin{array}{r}-0.013 \\
0.000\end{array}$ & $\begin{array}{r}-0.032 \\
0.000\end{array}$ & 0.41 & 0.42 & 0.48 \\
\hline $\begin{array}{l}\text { Nonmetropolitan/ } \\
\text { Trade Center }\end{array}$ & $\begin{array}{r}-0.020 \\
0.000\end{array}$ & $\begin{array}{r}-0.021 \\
0.000\end{array}$ & $\begin{array}{r}-0.019 \\
0.006\end{array}$ & 0.18 & 0.17 & 0.18 & $\begin{array}{r}-0.017 \\
0.000\end{array}$ & $\begin{array}{r}-0.024 \\
0.000\end{array}$ & $\begin{array}{r}-0.021 \\
0.020\end{array}$ & 0.24 & 0.27 & 0.24 \\
\hline $\begin{array}{l}\text { Nonmetropolitan/ } \\
\text { Trade Shed }\end{array}$ & $\begin{array}{r}-0.008 \\
0.000\end{array}$ & $\begin{array}{r}-0.009 \\
0.000\end{array}$ & $\begin{array}{r}-0.014 \\
0.000\end{array}$ & 0.30 & 0.35 & 0.40 & $\begin{array}{r}-0.018 \\
0.000\end{array}$ & $\begin{array}{r}-0.021 \\
0.000\end{array}$ & $\begin{array}{r}-0.033 \\
0.000\end{array}$ & 0.41 & 0.39 & 0.41 \\
\hline
\end{tabular}

Notes: Log Std Dev calculated using Equations 2 and 3. Beta estimated using Equation 4. Regressions include a constant. P-Values based on White (1980) heteroskedasticity corrected standard errors. Metropolitan counties are counties with Beale Codes 0 to 3. Nonmetropolitan counties are counties with Beale Codes 4 to 9 . Trade Center counties are counties that contain trade center cities in Rand McNally Trade Areas. Trade Shed counties are counties within Rand McNally Trade Areas that do not contain a trade center city.

Beta-coefficient estimates for both retail trade and services are consistently negative and statistically significant, although the magnitude of Beta differs across the two subperiods. Overall, the regression results imply that counties with low starting location quotients tended to exhibit faster growth during ensuing years than did counties with higher starting location quotients.

The results also suggest that the rate of convergence among location quotients generally fell during the 1979-1997 period compared to the 1969-79 period. Further, Wald test results (which are available from the authors upon request) indicate that there is a statistically significant difference between Beta coefficients from the 1969 to 1979 time period and the 1979 to 1997 time period.

Overall, the results generally support the case for significant intradistributional mobility. However, this mobility need not necessarily lead to a distribution with a lower standard deviation. As the first row of Table 2 shows, Sigma- 
convergence is not found for the retail trade or services industries in the South Census region, which indicates that the distribution is not simply converging to a single location quotient value.

\section{ii. Results by Metropolitan/Trade Center Classification}

The finding of significant intradistributional mobility accompanied by rising log standard deviations suggests that location quotients for retail trade and services in the South Census region are not converging to a single value. However, while the overall distribution may not be exhibiting convergence, we may still find that convergence is occurring in clubs, that is, subgroups of counties (for example, counties with a similar status in the central place hierarchy).

In fact, as was mentioned in the literature review section, central place theory suggests that location quotients should be similar for places of a similar size that have a similar relation to higher order places. Location quotients would not be expected to be the same in all counties, but might be close in groupings of similar counties, such as metropolitan trade center counties or nonmetropolitan trade shed counties.

Table 2 shows the results for Beta- and Sigma-convergence for metropolitan/ nonmetropolitan and trade center/trade shed counties for retail trade and services. The results consistently show significant mobility within the distribution, but do not suggest a trend toward a single-peaked distribution. Further, as with the overall results, we generally find lower mobility during the 1979-1997 period than for the 1969-1979 period.

However, there are some interesting differences across the central place hierarchy during the 1969-1997 period. For retail trade, we find significantly lower estimates of Beta for nonmetropolitan trade shed counties, indicating that counties with small populations that are not trade centers tend to exhibit less mobility within the distribution. Further, retail trade location quotients for these counties have also exhibited a strong increase in dispersion, as indicated by standard deviation figures in 1969,1979, and 1997. As Table 2 also shows, the deceleration in Beta-convergence during the 1979-1997 period was strong not just in the nonmetropolitan trade shed counties, but also for metropolitan counties.

Within the services distribution for the 1969-1997 period, we find that estimates of Beta are similar across the central place hierarchy, with the only significant difference being between the Beta coefficients for metropolitan trade center counties and nonmetropolitan trade shed counties. The slowdown in Betaconvergence during the 1979-1997 period is evident in services as well and is concentrated in metropolitan counties. In addition, we find strong increases in the log standard deviations for metropolitan trade center and metropolitan trade shed counties.

Finally, we also see significant differences between estimates of Beta for retail trade and services. The difference primarily arises from a lower estimate of 
Beta for retail trade in nonmetropolitan trade shed counties, which indicates greater mobility in the services distribution for these types of counties. ${ }^{5}$

\section{iii. Results by Two-Digit SIC}

Table 3 contains results by two-digit SIC for all retail trade sectors and selected services industries. We see the same general trends reflected in the onedigit SIC results: 1) location quotients generally decline over time; 2) log standard deviations rise over time; and 3) Beta coefficients are significantly different from zero.

\section{TABLE 3}

Means and Log Standard Deviations of Location Quotients South Census Region Counties

Retail Trade and Services Two-Digit SICs

\begin{tabular}{lrrrrrrrr}
\hline & Number of & \multicolumn{3}{c}{ Means } & \multicolumn{5}{c}{ Log Standard Deviation } & Beta \\
& Counties & 1969 & 1979 & 1997 & 1969 & 1979 & 1997 & $1969-97$ \\
\hline Retail Trade & 1,382 & 0.92 & 0.83 & 0.81 & 0.32 & 0.36 & 0.41 & $-.010^{* * *}$ \\
Hardware (52) & 901 & 1.33 & 1.16 & 1.03 & 0.58 & 0.49 & 0.60 & $-.025^{* * *}$ \\
General Merchandise (53) & 826 & 0.76 & 0.71 & 0.85 & 0.62 & 0.70 & 0.84 & $-.016^{* * *}$ \\
Food (54) & 1,304 & 1.07 & 0.98 & 1.10 & 0.37 & 0.33 & 0.34 & $-.020^{* * *}$ \\
Automobiles (55) & 1,343 & 1.04 & 0.98 & 0.88 & 0.38 & 0.38 & 0.54 & $-.012^{* * *}$ \\
Apparel (56) & 884 & 0.87 & 0.87 & 0.71 & 0.59 & 0.56 & 0.80 & $-.017^{* * *}$ \\
Furniture (57) & 1,005 & 0.97 & 0.86 & 0.65 & 0.50 & 0.48 & 0.75 & $-.023^{* * *}$ \\
Eating \& Drinking (58) & 1,238 & 0.77 & 0.68 & 0.74 & 0.54 & 0.57 & 0.54 & $-.016^{* * *}$ \\
Miscellaneous (59) & 1,339 & 1.15 & 0.89 & 0.81 & 0.48 & 0.42 & 0.48 & $-.023^{* * *}$ \\
& & & & & & & & \\
Services+ & 1,310 & 0.73 & 0.62 & 0.55 & 0.42 & 0.45 & 0.50 & $-.017^{* * *}$ \\
Hotels \& Motels (70) & 486 & 1.12 & 1.10 & 0.81 & 0.91 & 0.98 & 1.00 & $-.009^{* * * *}$ \\
Personal (72) & 1,217 & 0.85 & 0.81 & 0.77 & 0.43 & 0.41 & 0.48 & $-.022^{* * *}$ \\
Business Services (73) & 1,016 & 0.59 & 0.51 & 0.39 & 0.88 & 0.85 & 0.85 & $-.025^{* * *}$ \\
Auto Repair (75) & 1,180 & 1.08 & 0.81 & 0.73 & 0.55 & 0.47 & 0.55 & $-.029^{* * *}$ \\
Misc. Repair (76) & 944 & 1.14 & 0.96 & 0.90 & 0.60 & 0.56 & 0.68 & $-.023^{* * *}$ \\
Motion Pictures (78) & 132 & 1.49 & 1.42 & 1.07 & 0.77 & 0.80 & 0.81 & $-.009^{* * *}$ \\
Amusements (79) & 480 & 0.92 & 0.77 & 0.66 & 0.68 & 0.63 & 0.79 & $-.015^{* * *}$ \\
Health (80) & 1,295 & 0.79 & 0.66 & 0.69 & 0.63 & 0.68 & 0.68 & $-.018^{* * *}$ \\
Legal (81) & 1,074 & 0.67 & 0.52 & 0.41 & 0.62 & 0.56 & 0.75 & $-.020^{* * *}$ \\
Education (82) & 305 & 0.53 & 0.54 & 0.61 & 0.95 & 0.98 & 1.11 & $-.015^{* * *}$ \\
Membership (86) & 690 & 0.83 & 0.78 & 0.89 & 0.91 & 0.29 & 0.27 & $-.034^{* * *}$ \\
Household (88) & 1,167 & 1.28 & 1.10 & 1.14 & 0.61 & 0.75 & 0.66 & $-.021^{* * *}$ \\
Miscellaneous (89) & 1,207 & 0.67 & 0.60 & 1.26 & 0.73 & 0.61 & 0.69 & $-.026^{* * *}$ \\
\hline
\end{tabular}

Notes: Log Std Dev calculated using Equations 2 and 3. Beta estimated using Equation 4.

+ Results for SICs 83, 84, and 87 not shown due to nondisclosure.

* indicates significance at $10 \%$ level.

** indicates significance at $5 \%$ level.

$* * *$ indicates significance at $1 \%$ level.

General merchandise stores (SIC 53) and food stores (SIC 54) stand out from the rest of the retail industries. General merchandise stores registered increasing average location quotients, along with a rising level of dispersion. The

${ }^{5}$ Excluding medical payment transfers from our definition of income does not change the results. We find very similar average location quotients, log standard deviations, and Beta coefficients. Wald tests fail to reject the null of equality between Beta coefficients estimated using personal income and personal income less medical payments, for all county types. 
distribution of location quotients in this industry has tended to diverge (or spread out) during the last 28 years. Food stores also generated a rising average location quotient, but this was accompanied by a decline in the level of dispersion. In contrast, most retail sectors registered falling average location quotients and rising log standard deviations. In terms of Beta-convergence, food stores fall about in the middle of the pack while general merchandise stores recorded a relatively low Beta coefficient.

Within the services sectors, there is more diversity across average location quotients, log standard deviations, and Beta coefficients. However, it is important not to read too much into this because there is also more diversity in terms of the number and types of counties subject to nondisclosure. Four services industries (business services, automobile repair, membership organizations, and miscellaneous services) registered the same or smaller log standard deviations in 1997 than in 1969. These four sectors also registered relatively fast rates of Betaconvergence. Further, business services recorded strong declines in the average location quotient from 1969 to 1997. In addition, business services posted one of the lowest average location quotients in 1997, which indicates that smaller counties (in terms of personal income) tended to post smaller location quotients than larger counties.

The lowest rates of Beta-convergence were recorded by hotels and motels (SIC 70), motion pictures (SIC 78), amusements (SIC 79), and education (SIC 82). These sectors have also recorded increases in their log standard deviation during the 1969 to 1997 period. Overall, the travel-related services sectors have exhibited less intradistributional mobility in location quotients and have registered increasing inequality.

\section{Distributional Mobility by Quintile}

To this point we have seen that the shape of the overall distributions of retail trade and services location quotients have changed during the 1969 to 1997 period. The distributions show little tendency toward convergence, but do show signs of significant mobility within the respective distributions. In this section, we further examine the character and extent of location quotient mobility with the retail trade and services distributions. As was demonstrated earlier, Beta-convergence was significantly different during the 1969-1979 period and the 1979-1997 period. In order to avoid mixing results from two very different periods, we will focus on the 1979 to 1997 period in this section.

We measure mobility using the probability of moving from the first quintile (the lowest value) to the third quintile or higher over time, as well as the probability of moving from the fifth quintile to the third quintile or lower. In addition to intuitive appeal, this measure provides information on the ability of location quotients to move relatively large distances within the distribution, as well as indicating the presence of asymmetries between upward and downward mobility. 
Transition matrixes are a convenient way to summarize the dynamics of a distribution (see Bhat 1984). ${ }^{6}$ To fix ideas, Table 4 shows the transition matrixes for retail trade and services location quotients for trade center counties in the South Census region. We split the distribution in 1979 into quintiles and then observe movement across those quintile boundaries (defined using 1979 data) that has occurred by 1997. Thus, the first row of Table 4 shows that, of the trade center retail trade location quotients that started out in the first quintile (lowest quintile) in $1979,55.0$ percent were still in that quintile in 1997. Moving across the first row, we observe that of the counties with retail trade location quotients in the lowest quintile in 1979, 25.0 percent moved up to quintile 2 by 1997. Thus, entries on the diagonal give us the share of counties that were in the same quintile in both 1979 and 1997. Off-diagonal entries show movement across quintiles during the period.

\section{TABLE 4}

Trade Center County Transition Matrixes

Retail Trade and Services Location Quotients

South Census Region Counties, 1979-1997 (in percent)

\begin{tabular}{|c|c|c|c|c|c|}
\hline \multirow[b]{2}{*}{$\begin{array}{l}\text { Starting Quintile } \\
\text { (Boundaries in Levels) }\end{array}$} & \multicolumn{4}{|c|}{ Retail Trade } & \multirow[b]{2}{*}{$\begin{array}{c}\text { Percent of } \\
\text { Counties in } \\
\text { Quintile } 5 \\
\text { in } 1997\end{array}$} \\
\hline & $\begin{array}{l}\text { Percent of } \\
\text { Counties in } \\
\text { Quintile } 1 \\
\text { in } 1997\end{array}$ & $\begin{array}{l}\text { Percent of } \\
\text { Counties in } \\
\text { Quintile } 2 \\
\text { in } 1997\end{array}$ & $\begin{array}{l}\text { Percent of } \\
\text { Counties in } \\
\text { Quintile } 3 \\
\text { in } 1997\end{array}$ & $\begin{array}{c}\text { Percent of } \\
\text { Counties in } \\
\text { Quintile } 4 \\
\text { in } 1997\end{array}$ & \\
\hline $\begin{array}{l}\text { Quintile } 1-1979 \\
\text { (0 to } 0.977 \text { ) }\end{array}$ & 55.0 & 25.0 & 10.0 & 10.0 & 0.0 \\
\hline $\begin{array}{l}\text { Quintile } 2-1979 \\
\text { (0.977 to } 1.075)\end{array}$ & 30.0 & 30.0 & 30.0 & 7.5 & 2.5 \\
\hline $\begin{array}{l}\text { Quintile } 3-1979 \\
\text { (1.075 to } 1.167)\end{array}$ & 7.5 & 27.5 & 20.0 & 22.5 & 22.5 \\
\hline $\begin{array}{l}\text { Quintile } 4-1979 \\
\text { (1.167 to } 1.281)\end{array}$ & 5.0 & 12.5 & 27.5 & 40.0 & 15.0 \\
\hline $\begin{array}{l}\text { Quintile 5-1979 } \\
(1.281<)\end{array}$ & 2.4 & 7.3 & 17.1 & 26.8 & 46.3 \\
\hline
\end{tabular}

\begin{tabular}{lccccc}
\hline & $\begin{array}{c}\text { Percent of } \\
\text { Counties in } \\
\text { Quintile 1 } \\
\text { in 1997 }\end{array}$ & $\begin{array}{c}\text { Percent of } \\
\text { Counties in } \\
\text { Quintile 2 } \\
\text { in 1997 }\end{array}$ & $\begin{array}{c}\text { Percent of } \\
\text { Counties in } \\
\text { Quintile 3 } \\
\text { in 1997 }\end{array}$ & $\begin{array}{c}\text { Percent of } \\
\text { Counties in } \\
\text { Quintile 4 } \\
\text { in 1997 } \\
\text { (Boundaries in Levels) }\end{array}$ & $\begin{array}{c}\text { Percent of } \\
\text { Counties in } \\
\text { Quintile 5 } \\
\text { in 1997 }\end{array}$ \\
\hline $\begin{array}{l}\text { Quintile 1-1979 } \\
\text { (0 to 0.743) }\end{array}$ & 75.0 & 17.5 & 5.0 & 0.0 & 2.5 \\
$\begin{array}{l}\text { Quintile 2-1979 } \\
\text { (0.743 to 0.892) }\end{array}$ & 45.0 & 32.5 & 10.0 & 7.5 & 5.0 \\
$\begin{array}{l}\text { Quintile 3-1979 } \\
\text { (0.892 to 1.013) }\end{array}$ & 10.0 & 42.5 & 30.0 & 10.0 & 7.5 \\
$\begin{array}{l}\text { Quintile 4-1979 } \\
\text { (1.013 to 1.190) }\end{array}$ & 5.0 & 10.0 & 12.5 & 37.5 & 35.0 \\
$\begin{array}{l}\text { Quintile 5-1979 } \\
(1.190<)\end{array}$ & 0.0 & 0.0 & 2.5 & 17.5 & 80.0 \\
\hline
\end{tabular}

Notes: Quintile boundaries are adjusted for mean drift during the 1979-1997 period. Rows may not sum to 100 due to rounding.

${ }^{6}$ For the 1979 to 1997 period, quintile ranges in 1997 were defined to match those in 1979, adjusting for the drift in the mean location quotient value from 1979 to 1997 . Specifically, the percentage difference between the location quotient value at each quintile and the mean value in 1979 was calculated and then applied to the new mean value for the location quotient in 1997 . This makes it possible to examine how the distribution of the quintiles has changed apart from any trend drift in the mean location quotient value. 
For both the retail trade and services distributions, we see that trade center counties that start in the lowest (highest) quintile have a strong tendency to remain in that quintile 18 years later. For instance, within the services distribution, 75.0 percent of counties that were in quintile 1 in 1979 remained in that quintile in 1997. Likewise, 80.0 percent of location quotients that started out in quintile 5 in 1979 remained in that quintile in 1997 . However, only 32.5 percent of counties that began in quintile 2 in 1979 remained in that quintile in 1997. We observe a similar, but somewhat more moderate, pattern in retail trade. Overall, the transition matrixes strongly suggest that mobility is lower for location quotients on either end of the distribution, while mobility is higher for location quotients in the middle.

We can further refine these results by analyzing mobility within the distributions of metropolitan/nonmetropolitan and trade center/trade shed counties. Table 5 summarizes the probability of large increases (decreases) in retail trade and services location quotients using transition matrixes like those illustrated in Table 4. ${ }^{7}$ As the table shows, for trade center retail trade location quotients, the probability of moving from the lowest quintile to the middle quintile or higher is almost 36 percent. The probability of downward mobility is a bit larger, but similar in size. A trade center retail trade location quotient had to rise from 0.977 to at least 1.075 (a 10 percent increase) in order to rise from the lowest quintile to the middle quintile or higher. A trade center retail trade location quotient had to fall from 1.281 to 1.167 or lower (a 9 percent decrease) in order to fall from the highest quintile to the middle or lower.

Our results are different for trade center services location quotients, with much smaller probabilities of moving large distances within the distribution. A trade center services location quotient had to rise from 0.743 to 0.892 or higher (a 20 percent increase) in order to rise from the lowest quintile to the middle quintile or higher. A trade center services location quotient had to fall from 1.190 to 1.013 or lower (a 15 percent decrease) in order to fall from the highest quintile to the middle or lower.

For retail trade, overall mobility was highest for trade center counties, which is consistent with our results from Beta-convergence. This contrasts with the results for services, where we observe relatively low levels of upward and downward mobility in trade center counties. However, within trade center counties, services location quotient mobility is much greater for nonmetropolitan trade center counties than it is for metropolitan trade center counties. In addition, for the nonmetropolitan trade center counties, downward mobility exceeds upward mobility, while the reverse is true for metropolitan trade center counties. Finally, for both the retail trade and services distributions, downward mobility exceeded upward mobility by the largest margin for nonmetropolitan trade shed counties.

7 We iterate each transition matrix once, to provide a long-run estimate of the probability of moving up or down the distribution. 


\section{TABLE 5}

Likelihood of Movement within the Distribution South Census Region Counties, 1979-1997 (in percent)

\section{Retail Trade}

\section{Services}

$\begin{array}{cc}\begin{array}{c}\text { Likelihood of } \\ \text { Moving From }\end{array} & \begin{array}{c}\text { Likelihood of } \\ \text { Moving From } \\ \text { Quintile 1 to 3 } \\ \text { or Higher }\end{array} \\ \begin{array}{c}\text { Quintile 5 to 3 } \\ \text { or Lower }\end{array} \\ \text { (2 Transitions) } & \text { (2 Transitions) }\end{array}$

$\begin{array}{cc}\text { Likelihood of } & \text { Likelihood of } \\ \text { Moving From } & \text { Moving From } \\ \text { Quintile 1 to 3 } & \text { Quintile 5 to 3 } \\ \text { or Higher } & \text { or Lower } \\ \text { (2 Transitions) } & \text { (2 Transitions) }\end{array}$

23.0

11.4

25.5

42.7

31.9

37.7

34.2

37.2

30.7
20.1

14.4

21.5

14.4

24.1

14.8

25.4

37.3

24.0

21.4

4.5

36.1

8.9

37.4

10.5

20.0

44.2

40.7

Nonmetropolitan/

16.8

Notes: Metropolitan counties are counties with Beale Codes 0 to 3. Nonmetropolitan counties are counties with Beale Codes 4 to 9 . Trade Center counties are counties that contain trade center cities in Rand McNally Trade Areas. Trade Shed counties are counties within Rand McNally Trade Areas that do not contain a trade center city. Minimum distances required to transition from the lowest (highest) quintile to the middle or higher (lower) are available from the authors upon request.

\section{CONCLUSION}

One aspect of local economic development policy in the nonmetropolitan United States is the performance of local retail and services sectors. A number of programs attempt to enhance these sectors, such as downtown redevelopment, entrepreneurship development, and revolving loan funds. Such programs are found in many communities around the country, although retail trade and services development efforts are by no means as common as industrial recruitment efforts.

There certainly are opportunities to enhance local retail trade and services sectors and capture local spending through collective and individual initiative. However, economic approaches, such as central place theory, suggest that the ability of communities and counties to capture local retail and services spending may be limited by factors such as a county's population or its proximity to larger counties and cities. The relative importance of these determining factors of population and proximity can be gauged by examining the level of location quotients of counties of different sizes and different proximity to metropolitan areas.

This research examined movement among retail trade and services location quotients in South Census region counties during the period 1969 to 1997. In addition to looking at trends in the average location quotient value, we also examined the likelihood of significant movement by individual counties upward or downward within the distribution of location quotients. This revealed additional 
information about the potential for significant improvement or worsening in retail (or services) capture in individual counties over time. Convergence was examined for all South Census region counties together and for groups of counties classified by metropolitan/nonmetropolitan and trade center/trade shed status.

Beta-convergence (i.e., counties with smaller location quotients experience faster location quotient growth) was found for retail trade and services location quotients for both the 1969 to 1979 period and the 1979 to 1997 period. These findings occurred at the aggregate level and within all county classifications (and twodigit SICs). These findings regarding Beta-convergence, however, were often contradicted by results for Sigma-convergence. We conclude from this evidence that there is significant mobility within the distributions, but that the distributions do not show strong evidence of convergence.

Additional investigation of mobility revealed that for retail trade and services location quotients in the South Census region, counties with the lowest (highest) location quotients in 1979 tended to have about a 20 percent chance of moving to the middle of the distribution or higher (lower) by 1997. In general, we find that retail trade location quotient mobility is lowest (and primarily downward) for nonmetropolitan trade shed counties and highest for trade center counties. Within the services distribution we find the greatest mobility for nonmetropolitan and trade shed counties, although (particularly for nonmetropolitan trade shed counties) this mobility is primarily downward.

These findings suggest that location quotient values may not be converging consistently. Further, there is potential for counties to substantially raise location quotient values, that is, to capture a larger share of local spending. Both findings suggest that, despite declining location quotients in nonmetropolitan counties, there is potential for success with public programs designed to help local communities capture more local spending.

\section{REFERENCES}

Barro, Robert J., and Xavier Sala-i-Martin. "Convergence Across States and Regions." Brookings Papers on Economic Activity 1 (1991), 107-182.

Bernard, Andrew B., and Charles I. Jones. "Productivity and Convergence Across

U.S. States and Industries." Empirical Economics 21 (1996), 113-135.

Bhat, U. Narayan. Elements of Applied Stochastic Processes. 2d ed. New York: Wiley \& Sons, Inc., 1984.

Button, Kenneth, and Eric Pentecost. "Regional Service Sector Convergence." Regional Studies 27 (1993), 623-636.

Carlino, Gerald, and Leonard Mills. "Convergence and the U.S. States: A TimeSeries Analysis." Journal of Regional Science 36 (1996), 597-616.

Chatterji, M., and J.H.L.L. Dewhurst. "Convergence Clubs and Relative Economic Performance in Great Britain: 1977-1991." Regional Studies 30 (1996), 31-40. Christaller, Walter. The Central Places of Southern Germany. Englewood Cliffs, NJ: Prentice-Hall, 1933. 
Flora, Cornelia Butler, Jan L. Flora, Jacqueline D. Spears, and Louis E. Swanson. Rural Communities: Legacy and Change. Boulder, CO: Westview Press, 1992.

Gale, H. Fredrick Jr. "Retail Sales Pull Factors in U.S. Counties." The Review of Regional Studies 26 (1996), 177-196.

Harris, Thomas R., and J. Scott Shonkwiler. "Interdependence of Retail Businesses." Growth and Change 28 (1997), 520-533.

Hofer, Helmut, and Andreas Woergoetter. "Regional Per Capita Income Convergence in Austria." Regional Studies 31 (1997), 1-12.

Mankiw, N. Gregory, David Romer, and David N. Weil. "A Contribution to the Empirics of Economic Growth." Quarterly Journal of Economics 107 (1992), 407-437.

Quah, Danny T. "Galton's Fallacy and Tests of the Convergence Hypothesis." Scandinavian Journal of Economics 95 (1993a), 427-443.

. "Empirical Cross-Section Dynamics in Economic Growth." European Economic Review 37 (1993b), 426-434.

"Twin Peaks: Growth and Convergence in Models of Distribution

Dynamics." The Economic Journal 106 (1996a), 1045-1055.

. "Regional Convergence Clusters Across Europe." European Economic Review 40 (1996b), 951-958.

Rand McNally and Company. Commercial Atlas and Marketing Guide. 131st ed. Chicago, 2000.

Sala-i-Martin, Xavier. "The Classical Approach to Convergence Analysis." The Economic Journal 106 (1996), 1019-1036.

Shaffer, Ron E. Community Economics: Study of the Economic Structure and Change of Smaller Communities. Ames, IA: University of Iowa Press, 1989.

Shonkwiler, J. Scott, and Thomas R. Harris. "Rural Retail Business Thresholds and Interdependencies." Journal of Regional Science 36 (1996), 617-630.

White, H. "A Heteroscedasticity-Consistent Covariance Matrix Estimator and a Direct Test for Heteroscedasticity." Econometrica 48 (1980), 817-838.

Yanagida, John F., Bruce B. Johnson, Joel Young, and Michael Lundeen. "An Analysis of Economic and Noneconomic Factors Effecting Retail Sales Leakages." The Review of Regional Studies 21 (1991), 53-64. 